\title{
The Asian Century: More than just China
}

Lili Yan Ing $^{1^{*}}$ and Anika Widiana ${ }^{2}$

${ }^{1}$ Economist, Economic Research Institute for ASEAN and East Asia (ERIA) and Lecturer at Faculty of Economics, Indonesia

${ }^{2}$ Lecturer at Prasetiya Mulya Business School Jakarta. Indonesia

${ }^{*}$ Corresponding author: Lili Yan Ing, Economist, Economic Research Institute for ASEAN and East Asia (ERIA) and Lecturer at Faculty of Economics, Indonesia, Tel: +62-21-5797-4460; E-mail: liliyan.ing@eria.org

Received date: Jul 18, 2014; Accepted date: Aug 07, 2014; Published date: Aug 17, 2014

Copyright: ( 2014 Lili Yan Ing, et al. This is an open-access article distributed under the terms of the Creative Commons Attribution License, which permits unrestricted use, distribution, and reproduction in any medium, provided the original author and source are credited.

\begin{abstract}
This paper highlights the important role of the four Emerging East Asian Economies (EEA-4), namely Indonesia, Malaysia, Thailand and Vietnam in Asia. As China's growth pattern is changing as it moves up the income ladder, and is likely to rely more on consumption and less on investment and exports, and more on services and less on industry, these offer opportunities for EEA economies, particularly the EEA-4 to expand their economies through trade and investment. The EEA-4 could tap these opportunities as they have 3Ds: Durable macroeconomic, Domestic consumption and Demographic dividend. Nonetheless, they still face challenges of $3 C s$ : Credit, Competition and innovation and Confronting inequality. These economies should focus on how to optimize the growth potential of high value added sectors which will be beneficial for income growth and long-term prosperity. They have to be able to tap into its large pool of labor, while progressively moving up the value chain in the manufacturing and services sectors.
\end{abstract}

Keywords: Asian economies; Growth; Trade; Investment; Demographic dividend; Inequality

\section{Introduction}

East Asia Pacific (EAP) economic growth has outperformed world growth for the last two decades, except in 1997-1999 due to the Asian Financial Crisis. Compared with other regions, EAP had the highest growth in 2010 and the growth in developing East Asia Pacific remained strong in 2011, though slowed down from the rates that followed the global financial and economic crisis (Figures 1a and 1b). Most East Asian economies are well positioned to weather renewed volatility.

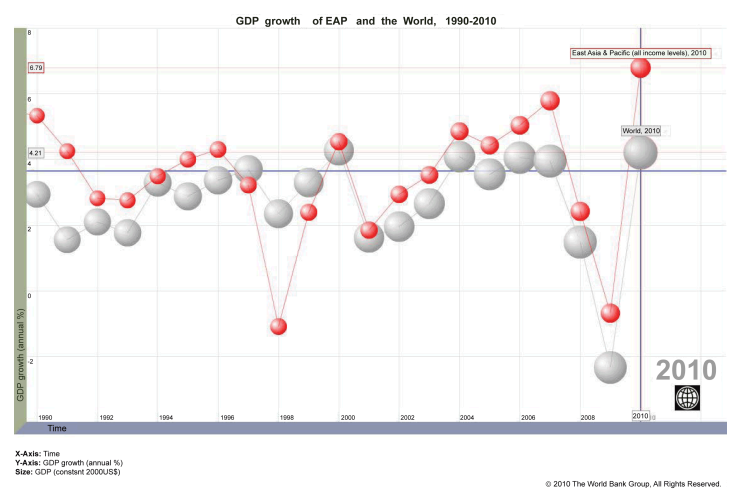

Figure 1a: GDP growth of EAP and the World, 1990-2010.

For 2012 and the following decade, we expect that East Asia will remain strong, even though annual growth will further moderate as a result of an unremitting volatile external environment. The growth lately was largely supported by strong domestic demand and investment as a result of the easing of monetary policy in several countries and was the main driving force of growth in the second half of 2011, partly offsetting decreased external demand from developed economies.

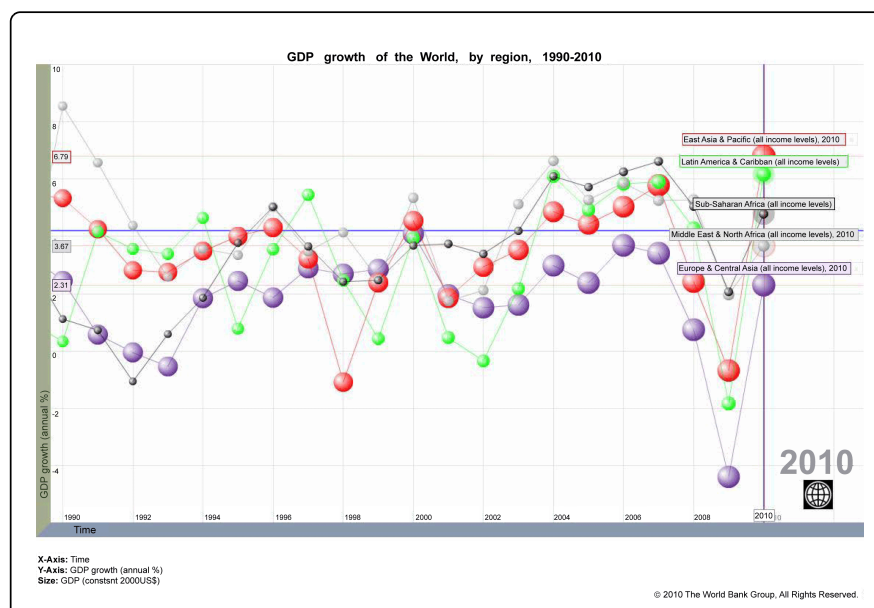

Figure 1b: GDP Growth of the World, by region, 1990-2010.

The drivers of global economic growth are shifting towards East Asia and Emerging Asian Economies are well-positioned to benefit from the growing power of Asian economies. Developing East Asia is estimated to grow by 7.6 percent in 2012, with slower expansion in China pulling down much of the regional aggregate [1]. Moreover, EEA-4 are also members of ASEAN. The ASEAN Economic Community (AEC) is intending to design ASEAN as a single production base which comprises free flow of goods, services, investment, and skilled labor. Further explanation on ASEAN as a single production network and single market can be found in [2]. 
Page 2 of 6

The four Emerging East Asian Economies (EEA-4) experienced strong growth in the last two decades, among the highest in the world. The average growth of the EEA-4 economies was 5 percent from 2000 to 2011. Economic growth of these economies decreased sharply in 2009 due to the slowdown in demand from the US and Europe as the final consumers of exports from these countries as a result of the Global Financial Crisis. Malaysia and Thailand experienced a decline in the economic growth of -1.5 percent and -2.3 percent in that year. In the case of Indonesia in particular, its main export destinations are China (14 percent), Japan (11 percent), U.S. (11 percent), and ASEAN (21 percent). Thus it is expected that the weakness of global economic eventually reduce demand for Indonesia's exports and thus affected its economic growth. In addition, the declined in global demand had already created a weakness in demand for primary and additional exports, and as a result of this the prices of commodities and mining product also decreased. The decline in export was not only experienced by Indonesia. Similar decline happened in Malaysia and Thailand [3].

However, these economies made a quick rebounded in 2010 as they could stood at an average of 7 percent of economic growth [4]. Despite the recent global crisis, Indonesia, Malaysia, and Vietnam grew at 6.5, 5 and 5 percent, respectively in 2011 [5]. The growth of the Emerging East Asia is estimated to be in par with China in the coming decade.

Section 2 illustrates how the four Emerging East Asian Economies (EEA-4) could be a new growth pole through trade and investment. Section 3 explains unique potency of EEA-4 and thus they could potentially be a new growth pole. Section 4 describes challenges that EEA-4 face. Last section draws the way ahead.

\section{Emerging East Asia: Southeast Asia as a New Growth Pole}

After a decade of China joining WTO, no one could afford for not to trade with China. Chinese products ranging from clothes to couches, from household electronics components to airbus components are all over the world, A growth pole here is referred to as an entity that has a high degree of growth and interaction with others and is dominant in that interaction based on the notions of external economies, agglomeration and linkages [6]. Nevertheless, export performance of EAP countries particularly China was anemic in 2011 and has weakened further in early 2012: growth in electronics exports has been flat as a result of slowing demand in Western Europe, the destination of 20 percent of direct electronics shipments. In 2012, China experienced the lowest growth since the last decade that is 7.8 percent from the previous year. In fact in early 2013, from January to March, China's economic growth fell from 7.7 percent to 7.5 percent. China's economic slowdown occurs along with the economic crisis in the U.S. and European Union. China's main export destinations are the EU and U.S. which accounted for 19 percent and 17 percent of China's total exports. While China's imports from the EU and Japan, respectively 12 percent and 11 percent of China's total imports. The crisis in the EU and the U.S. caused a decline in China's exports to the two of China main export destinations. China's net exports experienced a sharp decline in 2009 in the amount of 42 percent from 2008. The decrease in net export trend has been still occurring until 2012. Moreover, China has had both current account surpluses and capital account surpluses since 1994. Before 2005 the current account surplus was relatively small, but it reached 7.6 percent of GDP in 2007 $[4]$.
As a result of the large trade surplus, China accumulated foreign reserves rapidly. In 1990 its reserves were USD 11.1 billion, barely enough to cover 2.5 months of imports. Accompanying the rising trade surpluses was the rising trade deficit in the U.S. Therefore, China has taken steps to rebalancing its economic growth [7].

As China's growth pattern is changing as it moves up the income ladder, and is likely to rely more on domestic consumption and less on investment and exports, and more on services and less on industry, these offer opportunities for EEA economies, particularly Indonesia, Malaysia, Thailand and Vietnam to expand their economies through trade and investment.

Despite the intense competition from China, EEA-4 exports have remained strong. The value of exports of Asian economies (48 Asian economies) increased about 10 times in 2 decades [8]. It increased from USD 0.55 trillion in 1990 to USD 5.6 trillion in 2011. The EEA-4 maintained their contribution to total Asian exports to the world at around 15 percent throughout two decades (Figure 2).

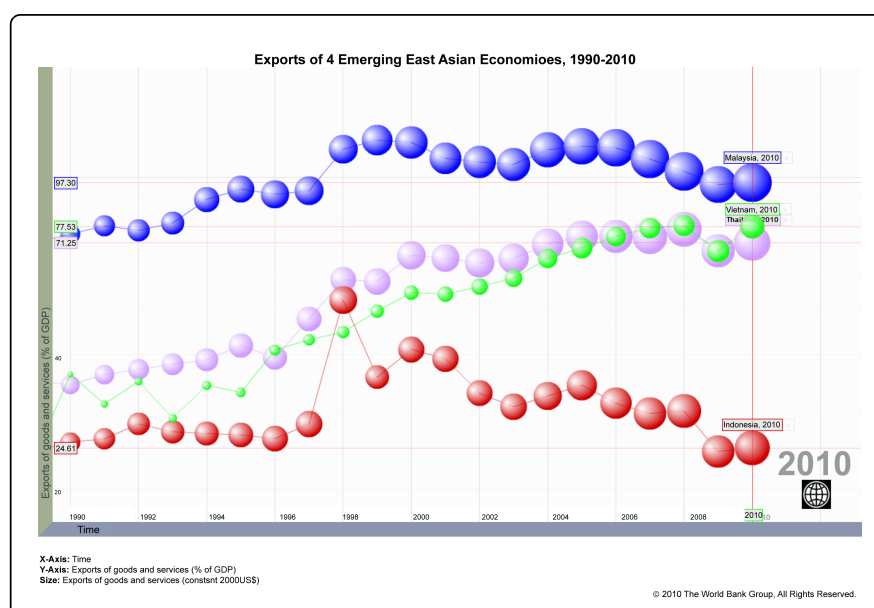

Figure 2: Exports of the Four Emerging East Asian Economies, 1990-2010.

At the same time, Emerging East Asian Economies will be increasingly important sources and drivers of global investment flows. Slow down and rebalancing of Chinese economy will drive movement of FDIs across Asia. There is a tendency of increasing movement in terms of not only capital inflows but also capital outflows (Figure 3). In terms of domestic investment Malaysia, Thailand, and Vietnam have a high enough financial accessibility.

The data shows that domestic credit provided by banking sector is quite high, that is above 110 percent to its GDP. While Indonesia still relatively low contribution of its domestic credit to GDP that is about 42 percent. The role of banks in lending to the industrial sector and the consumer is highly important, especially in EEA-4 [4].

\section{Unique Potency of the Four Emerging Asian Economies: 3Ds}

Despite the Global Financial Crisis, EEA-4 showed their resilient. Their economies remained strong due three main determinants. The first unique potency of the 4 EEA economies is strong economic growth decoupled with improved consumer confidence and less dependent to debt. 
Page 3 of 6

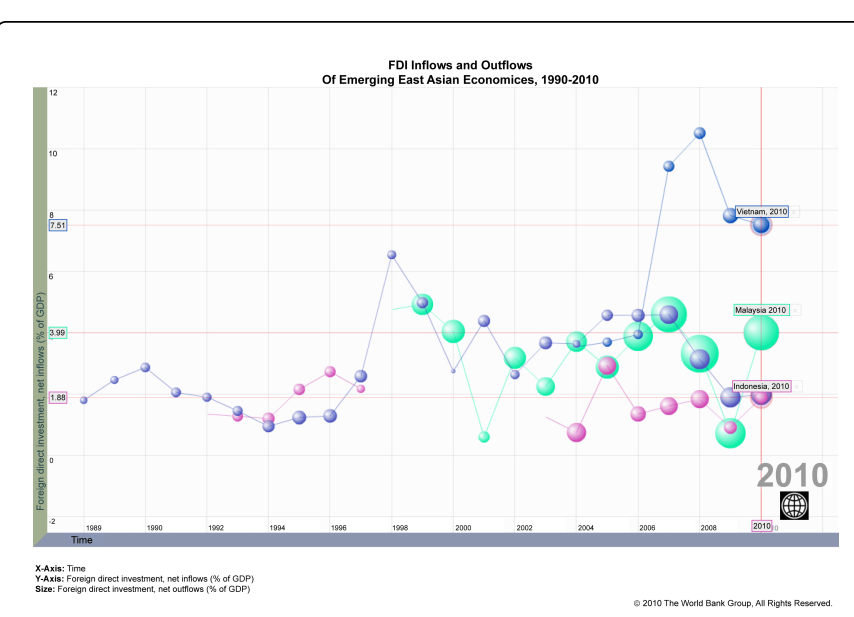

Figure 3: Capital Inflows and Outflows of the Four Emerging East Asian Economies, 1990-2010.

The 4 EEA economies experienced strong growth in the last two decades, among the highest in the world. The average growth of the 4 EEA economies was 5 percent from 2000 to 2011 [5]. The strong growth was accompanied by supported by improved consumer confidence index and less dependent on debt.

EEA-3 economies recoded a significant increase in consumer confidence after weakening from the global slowdown in 2008 when most economies recorded low consumer confidence index [9]. After recorded a low of 93 in third quarter of 2008, consumer confidence in Indonesia increased to 111 in the third quarter of 2012. Likewise, consumer confidence in Malaysia also increased from 71 to 118 over the same period. Thailand experienced a significant increase from 76 in the third quarter of 2008 to 83 in the third quarter of 2011, yet it dropped only 71 in the last quarter of 2011 which is thought to largely be due to severe flooding which damaged most of Bangkok areas including Nikom Rojna industrial estate which housed many manufacturing plants.

The improved of consumer confident index was also accompanied by less dependent on debt. The average ratio of total debt to GDP of these countries declined from the average of 60 percent in 2000 to 27 percent in 2011 (Figure 4). After the 1997 Asian Economic Crisis, most crisis-affected countries, particularly Indonesia and Thailand, have set lots of efforts in managing debt. The ratio of debt to GDP of Indonesia decreased from 90 percent in 2000 to about 25 percent in 2010. Thailand also successfully reduced its debt to GDP ratio from 65 percent in 2000 to 22 percent in 2010. Likewise, Malaysia and Vietnam also reduced their dependent on debt by reducing the ratio of total debt to GDP from 44 to 33 percent and from 41 to 34 percent, respectively, over the same period.

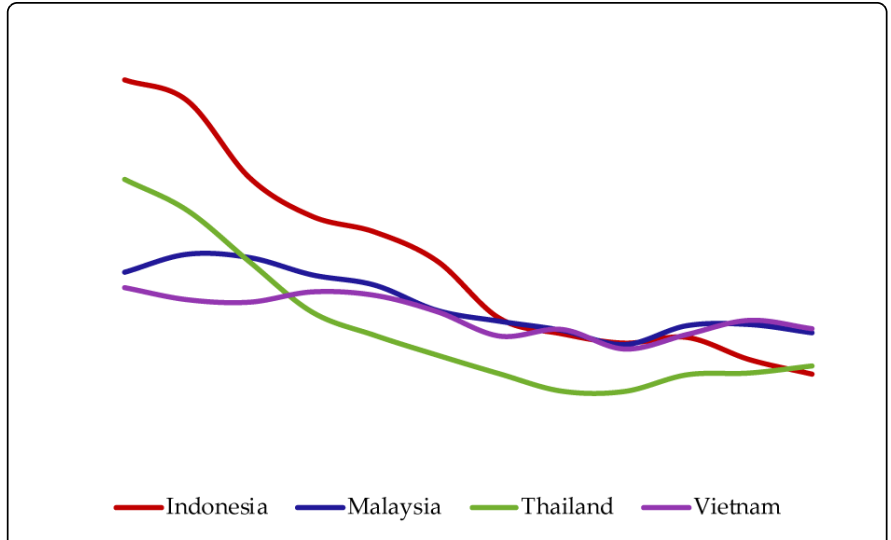

Figure 4: The Ratio of Total Debt to GDP (\%).

The second unique potency of the 4 EEA economies is the strong contribution of domestic consumption to GDP. Global economic outlook continues to deteriorate and financial markets continue to be volatile. Yet, as these economies relatively low exposed to the world market and strongly supported by domestic market with an average of about 65 percent of their GDP over 2000 to 2011, making these economies remain strong (Figure 5). Domestic consumption has contributed 67 percent, 55 percent, 63 percent and 73 percent to GDP in Indonesia, Malaysia, Thailand and Vietnam over 2000-2011, respectively. However, the lion share of domestic consumption to the economy should be interpreted with cautious. We do not argue that good direction for economies is that they should rely on domestic consumption, but more: first, these economies have opportunities to strengthen their economies by maintaining strong domestic demand and purchasing power by developing employment-driven-growth. Second these economies have large opportunities to expand their exports as well as investment.

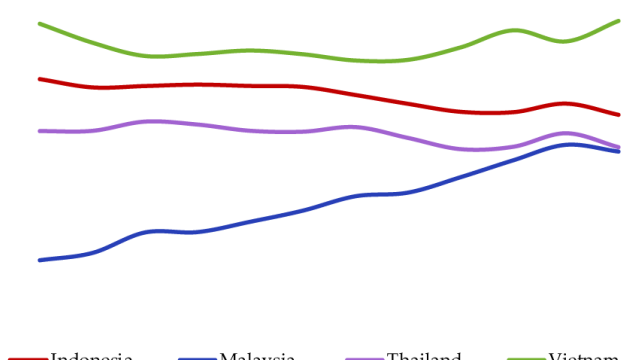

Figure 5: The Ratio of Consumption to GDP (\%).

The last unique potency the 4 EEA economies is Demographic Dividend. South East Asian (SEA) economies has become more attractive for investment due to two main reasons: SEA economies with its 600 million of population with an average of annual income per capita of Indonesia, Malaysia and Thailand of more than USD 3,500 in 2011 and the growing middle income class will become one of the most promising investment destinations in the coming decades. This is decoupled by the fact about 50 percent of population are in 
Page 4 of 6

labor force over the last decade with the labor productivity that is comparable with China yet lower changes real wages (Figures 6a and $6 \mathrm{~b})$. The growth of real wages has been lower than that of China, particularly since 2005. For an illustration, in 2011, labour cost per hour in China was USD 2.8, while it was only USD 0.8 in Indonesia and USD 0.4 in Vietnam [5]. Japan, the largest foreign direct investor for most South East Asian economies even place all the 4-EEA among the top ten of investment destinations [10].

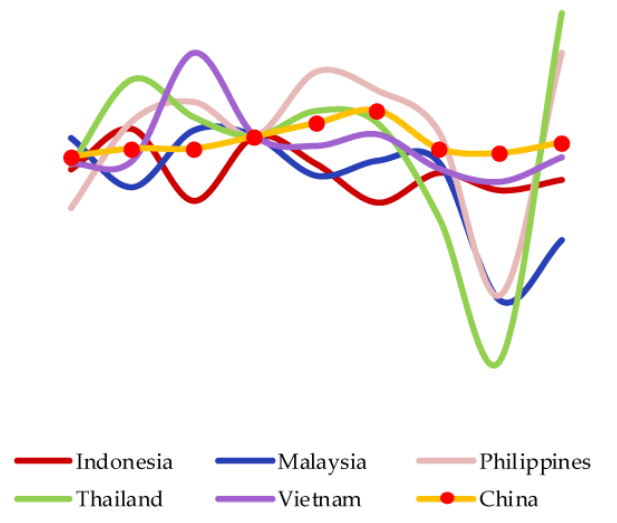

Figure 6a: Growth of Labor Productivity, 2005=100

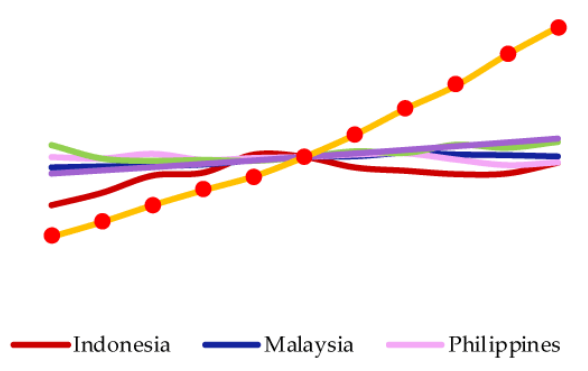

Figure 6b: Real Wages, $2005=100$

\section{Challenges for EEA-4: 3Cs}

There are at least three main challenges that EEA-4 face which could be summed up as 3Cs: Credit, Competition and Innovation and Confronting Inequality. First is Credit which is mainly about cost and access to finance. Indonesia, Thailand and Vietnam have relatively higher Net Interest Margin (NIM) than that of China from 2000-2010 (Figure 7a) [11]. This is decoupled by the fact that the firms in these countries face difficulties in access to finance, particularly for SMEs. For an illustration, based on Enterprise Surveys, 14, 15 and 26 percent of firms in Indonesia (2009), Malaysia (2007) and Thailand (2006) indentify that access to finance as a major business constraint (Figure $7 b)$. In addition, while Malaysia and Thailand have relatively high proportion of investments financed by banks as 53 and 33 percent, respectively, it was only 6 percent in Indonesia.

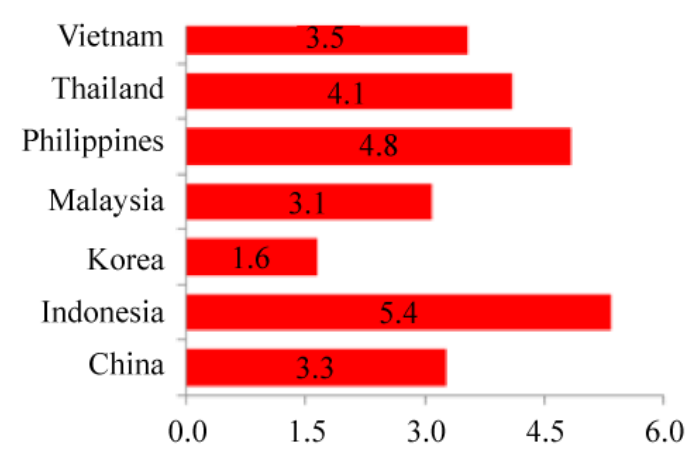

Figure 7a: Cost of Finance; Net Interest Margin, average 2005-2010 (\%).

Korea (2005)

Philippines (2009)

Indinesia (2009)

Malaysia (2007)

Vietnam (2009)

Cambodia (2007)

Lao PDR (2009)

Thailand (2006)

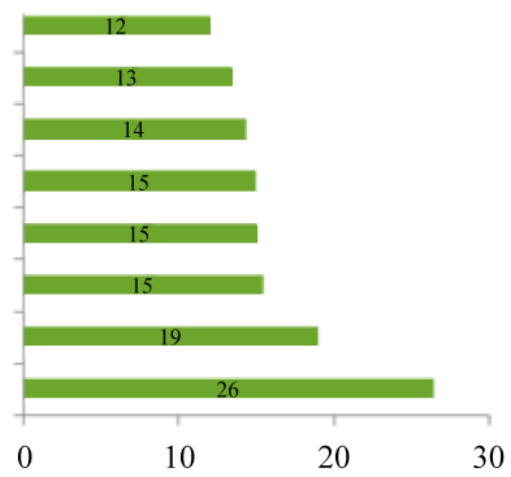

Figure 7b: Access to Finance; Percent of firms identifying access to finance as a major business constraint (\%) [12].

The second challenge for the Four EEA is Competition and innovation. The 4-EEA economies were still relatively closed to foreign investments compared with their peer countries in the region which perceived that can be one of barriers for competition (Table 1). Foreign equity caps were still relatively lower in most of sectors including mining, oil and gas, agriculture and forestry, manufacturing and most of services sectors, except Transportation, compared to that of the average ASEAN and EAP countries.

Moreover, low availability of skilled labour and relatively low activities on Research and Development (R\&D) may result in relatively insubstantial innovation. Indonesia and Malaysia still have relatively lower labour force with tertiary education compared to their peer countries in the region, notably the Philippines (Figure 8a); and in term of $\mathrm{R} \& \mathrm{D}$, the four EEA economies also have relatively lower ratio of R\&D expenditure to GDP compared to that of China and India (Figure 8b). 
Page 5 of 6

\begin{tabular}{|c|c|c|c|c|c|c|c|c|c|c|c|}
\hline Region/ & $\begin{array}{l}\text { Mining, } \\
\text { oil \& gas }\end{array}$ & Agri \& forestry & $\begin{array}{l}\text { Light } \\
\text { manf }\end{array}$ & Telcom & Electricity & Banking & Insurance & Transport & Media & $\begin{array}{l}\text { Const, tourism } \\
\text { \& retail }\end{array}$ & $\begin{array}{l}\text { Health } \quad \& \\
\text { waste } \\
\text { mgmt }\end{array}$ \\
\hline \multicolumn{12}{|l|}{ Economy } \\
\hline EAP & 78 & 83 & 87 & 65 & 76 & 76 & 81 & 66 & 36 & 93 & 84 \\
\hline China & 100 & 100 & 75 & 49 & 85 & 63 & 50 & 69 & 0 & 100 & 85 \\
\hline ASEAN & 72 & 78 & 87 & 62 & 71 & 75 & 83 & 61 & 32 & 92 & 82 \\
\hline EEA-4 & 67 & 77 & 83 & 49 & 61 & 66 & 70 & 67 & 24 & 85 & 68 \\
\hline Indonesia & 98 & 72 & 69 & 57 & 95 & 99 & 80 & 49 & 5 & 85 & 83 \\
\hline Malaysia & 70 & 85 & 100 & 40 & 30 & 49 & 49 & 100 & 65 & 90 & 65 \\
\hline Thailand & 49 & 49 & 87 & 49 & 49 & 49 & 49 & 49 & 28 & 66 & 49 \\
\hline Vietnam & 50 & 100 & 75 & 50 & 71 & 65 & 100 & 69 & 0 & 100 & 76 \\
\hline
\end{tabular}

Table 1: Foreign Equity Caps in EEA-4. Source: Ing, Lili Yan and Maur [13], Jean- Christope, ASEAN Investment Integration, ASEAN Integration Monitoring Report, World Bank. The data are based on Investment Across Border, 2010, accessed in August 2012 (forthcoming). Note: 1. There are no available data for Brunei, Myanmar and Laos.2. ASEAN is the average of equity caps in ASEAN countries, and EEA-4 is the average of equity caps in the four Emerging East Asia Economies, namely Indonesia, Malaysia, Thailand and Vietnam.

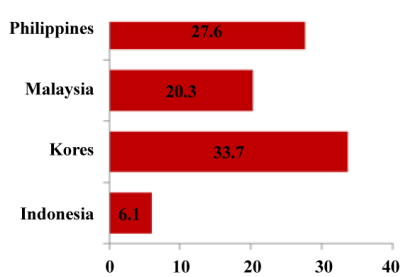

Figure 8a: Labor force with tertiary education (\%); average 2005-2010.

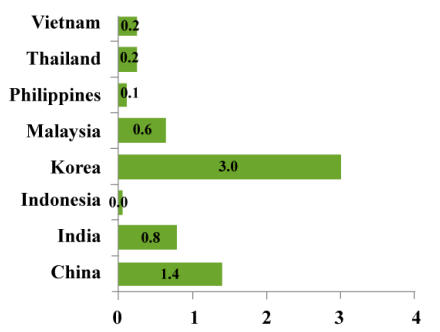

Figure 8b: Research and development expenditure (\% of GDP); average 2005-2010.

The last challenge for the four EEA and most developing economies is Confronting inequality. It is true that overall the number of people living in poverty has been cut in half in the last decade in East Asia and Pacific. Poverty continues to fall, with the number of people living on less than USD 2 a day expected to decrease in 2012 by 24 million [1]. Yet, as inequality has widened in Europe and the US since the 1980s, the rising inequality (note: inequality termed as 'the skill premium' is measured by the ratio of wages of skilled labour to wages of unskilled labour) is intriguingly also seen in developing economies, including Indonesia, Malaysia and Thailand (note: there are no sufficient data on Vietnam) [14]. While inequality within country may create social unrest, inequality across countries may challenge further integration.

\section{The Way Ahead}

In conclusion, the Asian Century is more than just China. The growing China and Korea could be a source for demand for resource based commodities, and manufacturing reallocation from China will be most likely to Emerging East Asian Economies. The 4 EEA economies will more likely become a new growth pole as they have 3Ds (Durable macroeconomic, Domestic consumption and Demographic dividend). Now, the next question is more on how they face challenges of 3Cs (Credit, Competition and innovation, and Confronting inequality).

In the short-term, first is improving credit which includes not only lowering cost of finance but also improving access to finance. There was weak appetite to use loans from financial institutions due to uncompetitive lending rates. One quick win could be providing incentives for good debtors to enjoy competitive interest rates by improving information-sharing on their debt and credit history. These should be accompanied by improvements in efficiency in the financial sector in order to reduce operating costs and thus provide competitive lending rates. At the same time, access to finance could be improved by providing temporary assistance for productive startups and improving the intermediation role of financial institutions. Start-ups tend to demonstrate relatively higher productivity growth and to create more employment than the average firm [15]. By focusing micro loan allocations on productive start-ups rather than on small and medium enterprises, resources would be allocated to relatively higher-productivity and employment-creation enterprises.

Second is improving competition and innovation. Further the opening of sectors to foreign investors. The four EEA economies still 
Page 6 of 6

restrict access for foreign investment more than comparable countries including the average ASEAN and EAP countries. The more open countries have tended to show that they have had more success generating Foreign Direct Investment (FDI) flows. These efforts should be pursued on a Most Favoured Nation basis. The more open policy should be accompanied by improving availability and quality of labor as well as providing incentives for training and R\&D to tap opportunities of transfer of knowledge generated from FDI.

Third is confronting inequality. While inequality within country may create social unrest, inequality across countries may challenge further integration. An increase in the skill premium (the ratio of wages of skilled labour to wages of unskilled labour) up to certain levels could be an incentive for individuals to be more educated and more skilled. In the early stage of development, might it be better to have a bigger cake with unevenly divided slices than a smaller cake cut into equal but tiny pieces? To address within country inequality, progressive tax could be introduced along the way with incentivizing firms for providing trainings. Simultaneously, to address inequality across countries, the EEA- 4 which are members of ASEAN should play more active roles in narrowing development gaps across countries the Southeast Asia region. The region could move forward in more unified manner if the poorest and most vulnerable people have the capacity to participate in the opportunities that will emerge as a result of further regional integration. If these opportunities are not realized then development gaps will diverge and inequality will increase. EEA-4 needs to work hard to improve institutional quality, both nationally and regionally, and to adopt a strong equity-driven perspective in all its activities, positively discriminating towards those countries that are lagging behind in development achievements [16].

In the medium-term, investment should be more focused on higher value-added and more innovation intensive activities. Although large gains have been made in labor productivity across the region since the Asian financial crisis of 1997-98, there is still large room for further gains. These economies should adopt a dual track management in managing resource based commodities while promoting efficient based activities. They should also focus on how to optimize the growth potential of high value added sectors which will be beneficial for income growth and long-term prosperity. To do this, they have to be able to tap into its large pool of labor and abundant natural resources, while progressively moving up the value chain in the manufacturing and services sectors. By doing so, the manufacturing and services sector will be able to provide more high value jobs as well as technology transfers. Moreover, the Emerging East Asian economies should also be able to tap opportunity driven by regional integration in trade in goods, services and investments.

\section{References}

1. World Bank (2012) East Asia and Pacific Economic Update, Capturing New Sources of Growth.

2. Kimura F (2013) Reconstructing the Concept of Single Market and Production Base for ASEAN beyond 2015, ERIA Discussion, pp:2013-25.

3. Basri M, Chatib (2011) The Impact of Global Financial Crisis on the Indonesian Economy, In Saw Swee-Hock (Ed.), Managing Economic Crisis in Southeast Asia (pp. 292-320), Singapore: ISEAS, 97.

4. The World Bank (2013) World Bank Open Data [Data file], Retrieved from http://data.worldbank.org/.

5. Economist Intelligent Unit, 2012.

6. A growth pole here is referred to as an entity that has a high degree of growth and interaction with others and is dominant in that interaction based on the notions of external economies, agglomeration and linkages.

7. Lin, Justin Yifu (2012) Demystifying the Chinese Economy, UK: Cambridge University Press, 17-18.

8. Author's calculations based on COMTRADE, 2012.

9. Tradingeconomics, 2012.

10. JETRO Survey, 2011.

11. Net Interest Margin is defined by the interest income minus interest charges or interest rate spread which is usually measured by lending rates minus deposit rate in percent.

12. The results are different from the percentage of firms put an order of top 10 major business constraints. For an illustration, 48 percent out of 1,444 firms in Indonesia (2009) places access to finance as the biggest obstacle for business, and 7 percent out of 1,115 firms in Malaysia (2007) places access to finance as the biggest obstacle for business (note: there are no sufficient data on the order of the biggest obstacle for business in Thailand from this survey).

13. Ing, Lili Yan (2009) Trade Expansion and Rising Skill Premium in Developing Countries, PhD Thesis, the Australian National University.

14. Fields G (1994) Changing labour market conditions and economic development in Hong Kong, the Republic of Korea, Singapore, Taiwan, and China. World Bank Economic Review 8: 395-414.

15. World Bank (2012) Picking up the Pace: Reviving Growth in Indonesia's Manufacturing Sector, Economic Sector Work on Indonesia's Manufacturing Sector, Jakarta: World Bank.

16. Carpenter, David, Mark McGillivray (2013) Narrowing the Development Gap: Policy Recommendations for ASEAN and Development Partners, In Mark McGillivray and David Carpenter (Ed.), Narrowing the Development Gap in ASEAN (pp. 178-200), New York: Routledge, 180-199. 